University at Buffalo School of Law

Digital Commons @ University at Buffalo School of Law

Books

Faculty Scholarship

2015

\title{
Laws of Image: Privacy and Publicity in America
}

\author{
Samantha Barbas \\ University at Buffalo School of Law, sbarbas@buffalo.edu
}

Follow this and additional works at: https://digitalcommons.law.buffalo.edu/books

Part of the Constitutional Law Commons, Courts Commons, Critical and Cultural Studies Commons, Law and Society Commons, and the United States History Commons

\section{Recommended Citation}

Samantha Barbas, Laws of Image: Privacy and Publicity in America (Stanford University Press 2015)

Excerpt from LAWS OF IMAGE: PRIVACY AND PUBLICITY IN AMERICA, by Samantha S. Barbas. (c) 2015 by the Board of Trustees of the Leland Stanford Jr. University. All rights reserved. No reproduction, distribution or any other use is permitted without the prior permission of the publisher, Stanford University Press, sup.org.

CC ${ }_{\mathrm{CO}}^{\mathrm{N}}$

This Book is brought to you for free and open access by the Faculty Scholarship at Digital Commons @ University at Buffalo School of Law. It has been accepted for inclusion in Books by an authorized administrator of Digital Commons @ University at Buffalo School of Law. For more information, please contact lawscholar@buffalo.edu. 
Excerpt from LAWS OF IMAGE: PRIVACY AND PUBLICITY IN AMERICA, by Samantha S. Barbas. (c) 2015 by the Board of Trustees of the Leland Stanford Jr. University. All rights reserved. No reproduction, distribution or any other use is permitted without the prior permission of the publisher, Stanford University Press, sup.org. 


\section{Introduction}

\section{Our Images, Our Selves}

After receiving calls from her neighbors, a woman found that her daughter's picture had been used in an ad for a local ice cream store, without the daughter's or the mother's consent. Her daughter had simply "liked" the ice cream store on Facebook. The woman was outraged and embarrassed. People across the country whose photographs had been similarly exploited under Facebook's Sponsored Stories advertising program sued Facebook. ${ }^{1}$

In 1948, the Saturday Evening Post ran a critique of cabdrivers in Washington, D.C., that accused them of cheating their customers. A photograph appeared with the article that depicted a woman cabdriver, Muriel Peay, talking to the article's author on the street. The caption did not name her, and the article did not refer to her. Although the woman had consented to be photographed, she did not know that the picture would be used in an article on cheating cabbies. She was humiliated, and she sued the magazine. ${ }^{2}$

In the early I940s, Zelma Cason, who was the inspiration for a character in a book by a famous writer, sued the author. The portrayal of Cason was highly complimentary, although in one part of the book the author described her as an "ageless spinster resembling an angry and efficient canary" and noted that she used profanity. Cason was upset, and she sought damages of one hundred thousand dollars. ${ }^{3}$

Angry and insulted, these people could have done any number of things. On seeing her picture in the Saturday Evening Post, Muriel Peay could have gone home and cried. Perhaps she did. The unwilling subjects of the Sponsored Stories program could have boycotted Facebook-perhaps they did, too. But these individuals also chose to sue. In the past hundred years, in increasing numbers, Americans have turned to the law to help them defend and control their public images. The twentieth century saw the creation of what I describe as a law of public image, and the phenomenon of personal image litigation. 
Under these laws of image, you can sue if you've been depicted in an embarrassing manner, even if no one thinks less of you for it. If a newspaper or website publishes your picture in a way you find offensive, you can, under certain circumstances, receive monetary damages for your sense of affront - for the outrage that someone has taken liberties with your public image and interfered with the way you want to be known to others. One's image or public image is one's public face or persona, the impression one makes on the world. One's deeds, dress, gestures, speech, looks, even one's online presence-all are elements of public image. An image is something that one has, and that one creates: most of us, in some form or another, are trying to project a particular image of ourselves, an image that we hope will stick with others. Reputation, as we will see, is an aspect of public image, a dimension of one's public persona. The laws of image protect the right to control one's public image, to defend one's image, and to feel good about one's image and public presentation of self. These image laws consist of the tort actions, or civil legal actions, for invasion of privacy, libel, and intentional infliction of emotional distress.

Why does the law in the United States acknowledge rights to control one's public image? Why does the American legal system permit recovery for tarnished images and hurt feelings? Why have so many mobilized the law to defend their public images? This book explains how and why these laws of image came to be. It is not a history of the law alone; it is a story about the interrelationship of law and culture-how these laws were shaped by cultural forces, and what they tell us about American society and its values, beliefs, and preoccupations. The development of image law is part of a broader saga about how Americans became fascinated with, perhaps even obsessed with their personal images.

Since the turn of the twentieth century if not earlier, the United States has been an image society. Images surround and besiege us - in advertisements, in newspapers and magazines, on billboards, throughout the cultural landscape. We are highly attuned to looks, impressions, and surface appearances. Perhaps no image is more seductive to us than our own image. In I96I, the historian Daniel Boorstin observed that when people talk about themselves, they talk about their images. ${ }^{4}$ If the flourishing industries of image management-fashion, cosmetics, photography, press agentry, and so on-are any indication, we are indeed deeply concerned with our looks, social appearances, and the impressions that we make. 
Our celebrity sagas and rags-to-riches stories describe people catapulted to wealth and fame because of their images. We have invested billions of dollars and many hours in our images and have burdened them with great emotional and psychological weight. In the stories we tell about happiness and achievement, images are the key to prosperity, social acceptance, and personal well-being.

The laws of image, I argue, are a manifestation of this image-conscious sensibility. They reflect a focus on images that has been, for over a hundred years, essential to our visions of self and personal identity. This book will illustrate how the laws of image are the expression of a people who have become so publicity-conscious and self-focused that they believe they have a right to control their public images, to manage and spin them like actors, politicians, and rock stars.

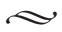

The story begins in urban America in the late nineteenth century, a time of profound social, cultural, and technological transformation. In contrast to small towns, where people knew each other intimately, newcomers to the burgeoning cities found themselves strangers, often known to each other only as superficial images: through newspaper stories, photographs, quick glances on the street. Urban dwellers began to conceptualize their social identities in terms of images and surface appearances, and sought to make positive first impressions on others through careful manipulation of their looks and behavior. They also became sensitive to threats to their public images, particularly from the new mass-market press. Beginning in the I880s, in what would become a long and venerable tradition, the popular press began to trade in "gossip" and other intimate accounts of personal life. The press was becoming an industry of counterimage, devoted to undermining people's public images and social facades. In unprecedented numbers, the subjects of undesirable media coverage sued the press for libel, the law's traditional, age-old remedy for injuries to reputation.

The tort of libel dealt with false statements that lowered one's standing among one's peers, statements that caused a person to be scorned or shunned by his community. Libel did not always or adequately address the problem of media gossipthe publication of facts that were often true, and that did not necessarily injure one's reputation, but nonetheless caused humiliation and distress. In many cases, the subjects of gossip were upset not only by the embarrassing depictions, but 
even more by the fact that they had lost control of their images, that the media had taken from them their prerogative to determine how they would be known to the world. The search for legal remedies for the gossip problem led to the invention of the "right to privacy." Proposed in I890, the right to privacy was a right to not have one's picture or personal information displayed to the public against one's will, in a humiliating or upsetting manner. Long before it offered protection against unauthorized data collection, government spying, or intrusions into one's private space, the right to privacy was the right to control one's public image, and to be compensated for emotional distress when the media interfered with one's own, desired public persona. The right to privacy was an expression of the nascent image-conscious sensibility.

By the mid-twentieth century, a legally enforceable right to privacy had been accepted in most American jurisdictions. It was part of a larger body of image law that had come into being, as courts and legislatures sought to give people greater control and protection of their public images in an age of proliferating mass communications. Plaintiffs could bring suit under the new tort of intentional infliction of emotional distress to compensate their hurt feelings when they were publicly depicted in an embarrassing fashion. Statutes imposed liability for the use of people's visual images without consent. In a historic shift, libel law was expanding to remedy not only harms to reputation but injuries to one's feelings when the media portrayed a person in a manner he found upsetting, even if the depiction was benign in others' eyes. The volume of lawsuits brought under these image torts rose steadily, and personal image litigation became a fixture of the legal landscape. Courts and commentators described the ability to control one's public image as an important personal right, linked to cultural ideals of freedom and self-determination.

The rise of these image torts and personal image litigation tracked mounting concerns with images, social appearances, and self-presentation in public. By the postwar era, cultural forces such as advertising, celebrity, the fashion industry, and popular psychology encouraged people to view their public images as the expression and summation of their inner selves. Controlling and perfecting one's public image was described as the key to personal, social, and material success. Critics observed an "other-directed" self — a personality type consumed with one's image and the act of constructing a pleasing public facade. By the I990s, plastic 
surgeons, personal image consultants, and "reputation managers" were in high demand in a world where, to quote a 1990 ad campaign, "image is everything." In recognizing injuries to public image as worthy of legal attention, and in some cases monetary judgments, the law contributed to the cultural focus on images and the construction of the modern image-conscious self.

And yet, American laws do not protect the right to one's public image and persona as extensively as in other parts of the world. ${ }^{5}$ In some European countries, under certain conditions, newspapers or websites can be forbidden from publishing ostensibly newsworthy pictures of people, or facts in the public record, without the subject's authorization. ${ }^{6}$ This broad protection of public image would be unimaginable in the United States. Since the I940s, the image torts have been substantially constrained by freedom of speech and press, and it is difficult to recover under them. Despite this, the laws of image remain alive, not only on court dockets but in legal culture-in Americans' beliefs about the law, the legal system, and their legal rights and entitlements. ${ }^{7}$

The free speech restrictions on the image torts represent another dimension, perhaps the flip side, of modern image-consciousness. In a culture where images have been the currency of social exchange, where politics and social life have been mediated by images, the ability to freely disseminate images of people and public affairs has been linked to "free and robust" public debate and discussion, often described as one of the core values of the First Amendment. Expressive freedom in the United States has come to embody two competing ideals. It means the freedom to express oneself through one's public image- to create and define one's own public persona and social identity. At the same time, it is the freedom to make and distribute images of other people, even if caustic, embarrassing, or unflattering. The tension between these competing freedoms is a central theme in the history that follows. We want to control our own images, yet we want to be able to tear down other people's images, freely and without restriction.

\section{$\propto$}

A social, cultural, and legal history of the laws of image and personal image litigation from the late nineteenth century to the late twentieth century, this book is novel in its conception. No book to date has envisioned this body of law as image law, oriented around the individual's interest in controlling, defending, ma- 
nipulating, and perfecting his public image, an interest that grew from the social pressures and circumstances of the United States in the twentieth century. ${ }^{8}$ There is a vast body of literature by legal scholars on the technicalities of libel and privacy law; critics and historians have also written a good deal on the significance of “images"—visual images, advertising, media images, celebrity images—in American cultural history; but no one has drawn the important connection between the two.

There are three key players in this story, and the narrative revolves around their competition, cooperation, and interaction. The first is the law and its formal architects, primarily courts and legislatures. I explain how the laws of image, principally libel and privacy law, developed over the twentieth century, and how the scope of these laws expanded to reach a range of perceived harms to people's public images and their feelings about their images. The extension of the law to address these sorts of injuries was historically significant; the law, for the most part, had not dealt with so-called intangible harms, injuries that were not to one's property or body. The creators and distributors of the mass media-newspapers, magazines, books, television, and film-also play a central role. These were the most common defendants in personal image lawsuits and in their own right important in the making of image law. The laws of image, in turn, substantially shaped media content.

The star of the story is the admittedly elusive "ordinary American," an individual who is not a celebrity, famous person, or public official. This work is a history of the average person and his struggles to preserve and control his public image. It attempts — as inevitably imprecise as the project may be-to track a sense of popular consciousness. Much attention has been given to celebrities and politicians, their public images, and their libel and privacy lawsuits, obscuring the image-consciousness of ordinary people and their efforts to use the law to defend their public images. Many libel and privacy cases in U.S. history have been brought by average citizens, not famous people, and often of quite humble background. A broad range of Americans have come to regard their public personas not only as social phenomena, to be negotiated through social interactions, but as legal entities, to be maintained and managed through the use of law and legal institutions. This legalization of personal image marks an important development in the history of the law and the modern history of the self. 